\title{
Learning Anxiety of Undergraduate Students during COVID-19 Pandemic
}

\author{
Kittiphong Phanchamlong \\ Faculty of Education, Mahasarakham University, Thailand \\ Kullasatree Manee \\ Faculty of Education, Mahasarakham University, Thailand \\ Nuttapong Watwiset \\ Faculty of Education, Mahasarakham University, Thailand \\ Prasart Nuangchalerm (Corresponding author) \\ Faculty of Education, Mahasarakham University, Thailand \\ E-mail: prasart.n@msu.ac.th
}

Veena Prachagool (Corresponding author)

Faculty of Education, Mahasarakham University, Thailand

E-mail: veena.p@msu.ac.th

Received: December 9, 2021 Accepted: January 16, 2022 Published: February 8, 2022

doi:10.5296/jei.v8i1.19313 URL: https://doi.org/10.5296/jei.v8i1.19313

\begin{abstract}
As we known the pandemic situation leads our social activity and learning practices changes, Online learning is the alternative choice for engaging students to classroom, but it is necessary may be students and teachers are unfamiliar with uncommon situation. The purpose of this research was to study learning anxiety of undergraduate science students during COVID-19 pandemic. The informants are 107 undergraduate science students enrolled course in the first semester, academic year 2021. The research instrument is developed as
\end{abstract}


learning anxiety questionnaire which consisted aspect of time, instruction, and online communication. Descriptive statistics are employed for data analysis, data is interpreted by mean and standard deviation to explain level of learning anxiety. Finding showed that science students had leaning anxiety in aspect of time, instruction and online communication are at the high level. It indicated students are unfamiliar with virtual or online classroom, but they need to adapt themselves to learn and survive with this period of uncommon learning. This situation needs instructional practices through flexible learning and suitable effective ways for helping students achieve in their potential learning.

Keywords: Instruction, Learning anxiety, Online learning, Pandemic, Teaching

\section{Introduction}

Social distancing is now familiar with new normal situation, due to COVID-19 pandemic has increased in many countries and trespassing to normal classroom (Bond, 2020). The endless signal of this situation cannot predictable, but social movement and educational activities should be moved on in such appropriated solutions (Engzell et al., 2021; Nuankaew et al., 2021; Phattanawasin et al., 2021). Ministry of Education, and Ministry of Higher Education, Science, and Innovation announced the closure of educational institutions has been closed, which has caused various impacts on learners. Whether anxiety, social and health can be changed, school needs to prevent students from diseases in various ways including the use of masks. Avoid going to crowded communities as well as social distancing. Washing hands frequently, some establishments have suspended work or work from home to reduce the spread of COVID-19 (Marome \& Shaw, 2021).

It's a crunch effect on degrading revenues, this make it inadequate to spend on the part of themselves and their families. As a result of the closure of businesses to reduce the gathering of many people, which may have caused the pandemic. People need to change their behavior in life activities, social adaptation including in the education system, to change the learning style, teaching, to education through online format (Pal et al., 2020; Thanavisuth, 2021). Education through the online format is the instruction of the content of the lesson consisting of text. Images, audio, and other multimedia are sent to learners via web browser from instructor to learners.

The learning atmosphere in this situation seems to be new normal or uncontrollable for face to face classroom. While the learning activities and social interaction are required, the alternative way to solve this problem in learning and teaching through the time of pandemical chaos. The online learning or virtual face to face is more productive to all sector and help us to prevent an infection. The communication changed and discussed as well as regular classes based on modern online communication tools, but online learning is still very limited (Polydoros \& Alasona, 2021).

As a result, students face a lot of pressure in terms of studying. Family, finance and society require adaptation to the situation, but if they are unable to adapt, there can be tensions to the problem of validity, which is one of the emotional feelings. This plays an important role in individual adaptation. It may be made a negative psychological effect in teaching and 
learning during pandemic time. Frustration can be emerged in social, psychological, health, economical, cultural, and also instructional movement. This study, researchers interested in learning anxiety in online learning in the situation of the pandemic of undergraduate science students, to benefit the problem solving and teaching and teaching efficiency in the future.

\section{Method}

This study employed survey method to investigate learning anxiety of undergraduate science students. The details can be described as follows.

\subsection{Informant}

One hundred and seven undergraduate science students are volunteering participation in this study. They are undergraduate students who are studying in the Faculty of Science, Mahasarakham university who enrolled in the first semester, Academic year 2021. They can help community to prevent the COVID-19 dispersion by taking social distancing and learn from home. Even though they need to participate learning and working with normal situations, online learning or virtual face to face is set for safe, internet is the gate to a meeting point among instructors, students, and other people.

\subsection{Research Tool}

The research tool is learning anxiety questionnaire of undergraduate science students, with 5-rating scale, 20 questions. The questionnaire is divided into two parts: Part 1: learning anxiety of undergraduate science students consisted of time, instruction, and online communication. The level of learning anxiety characterized by a 5-level estimation scale: 5-highest level of learning anxiety, 4-high level, 3 moderate level, 2-low level, and 1-lowest level in the following. Part 2: open-ended questionnaire for free opinion. Research tool was validated by 3 experts in field of education, learning assessment, and learning development.

\subsection{Data Collection and Analysis}

The researchers collected data by using Google form questionnaire to a group of informants in September 2021. The researchers examined the accuracy and integrity of the data which can be analyzed the data using basic statistics, including mean and standard deviations, and then compared the average scores obtained against the learning anxiety level. The level of learning anxiety can be calculated and interpreted mean ranges 4.51-5.00 highest level of learning anxiety, 3.51-4.50 high level, 2.51-3.50 moderate level, 1.51-2.50 low level, and 1.00-1.50 lowest level respectively.

\section{Result and Discussion}

Undergraduate science students had high level of learning anxiety towards instructional activities in the period time of COVID-19 pandemic (Table 1). The overall components of learning anxiety which consisted of time, instruction, and online communication showed at high levels. Some items may be highest or moderate, it can be indicated that level of learning anxiety concerns of what they perceived and response to the pandemic situations.

Students had the level of learning anxiety towards pandemic and learning environments is at 
high level. The component in learning anxiety is analyzed. They had leaning anxiety with time at high level by the most items can be shown in following: student has experience with anxiety while taking the exam due to less time to take the exam, student has anxiety that the Internet will have problems or signal failures while studying and will not be able to study in time, and student has anxiety about content due to less duration of study in respectively.

They had leaning anxiety with instruction is at high level by the most items can be shown in following: student has experience and anxiety when the instructor simultaneously dictates several subjects and is similarly due to date, student is anxious for learning assignments in online teaching as a group work, student has anxiety in the field of understanding of the content of online instruction, and student has anxiety with some teacher-taught applications because they have never used them before in respectively.

Table 1. Level of learning anxiety

\begin{tabular}{|c|c|c|c|}
\hline Component & Mean & S.D. & $\begin{array}{l}\text { Level of } \\
\text { learning anxiety }\end{array}$ \\
\hline \multicolumn{4}{|l|}{ Time } \\
\hline 1. Student has anxiety about content due to less duration of study. & 4.08 & 1.09 & High \\
\hline 2. Student has anxiety in graduating according to the semester calendar. & 4.04 & 1.12 & High \\
\hline $\begin{array}{l}\text { 3. Student has anxiety at the work assigned by the instructor due to the } \\
\text { less time period. }\end{array}$ & 4.05 & 1.08 & High \\
\hline $\begin{array}{l}\text { 4. Student has anxiety that the Internet will have problems or signal } \\
\text { failures while studying and will not be able to study in time. }\end{array}$ & 4.12 & 1.23 & High \\
\hline $\begin{array}{l}\text { 5. Student has experience with anxiety while taking the exam due to less } \\
\text { time to take the exam. }\end{array}$ & 4.52 & 0.87 & Highest \\
\hline $\begin{array}{l}\text { 6. Student has anxiety when instructors give too little time to present their } \\
\text { online academic work. }\end{array}$ & 3.78 & 1.14 & High \\
\hline Overall & 4.10 & 1.09 & High \\
\hline \multicolumn{4}{|l|}{ Instruction } \\
\hline $\begin{array}{l}\text { 1. Student has experience and anxiety when the instructor simultaneously } \\
\text { dictates several subjects and is similarly due to date. }\end{array}$ & 4.54 & 0.78 & Highest \\
\hline $\begin{array}{l}\text { 2. Student is confused when the image or slide does not match the } \\
\text { instructor's voice. }\end{array}$ & 3.71 & 1.16 & High \\
\hline $\begin{array}{l}\text { 3. Student is anxious for learning assignments in online teaching as a } \\
\text { group work. }\end{array}$ & 4.37 & 0.92 & High \\
\hline $\begin{array}{l}\text { 4. Student has anxiety in teaching operations in an online laboratory } \\
\text { format. }\end{array}$ & 4.28 & 0.94 & High \\
\hline
\end{tabular}




\begin{tabular}{|l|l|l|l|}
\hline $\begin{array}{l}\text { 5. Student has anxiety in the field of understanding of the content of } \\
\text { online instruction. }\end{array}$ & 4.36 & 0.89 & High \\
\hline $\begin{array}{l}\text { 6. Student has anxiety with some teacher-taught applications because } \\
\text { they have never used them before. }\end{array}$ & 4.36 & 0.93 & High \\
\hline $\begin{array}{l}\text { 7. Student has anxiety with clothes, faces and hairstyles. When the } \\
\text { instructor turns on the camera while studying online. }\end{array}$ & 3.27 & 1.19 & Moderate \\
\hline Overall & 4.01 & 1.04 & High \\
\hline
\end{tabular}

\section{Online communication}

1. The student's device is limited, causing anxiety that they cannot enter multiple programs at once.

2. Student has anxiety that the Internet will fall off while studying online.

3. Student has anxiety when submitting work, there is no response from the instructor.

4. Student has anxiety about interacting, questioning or consulting with instructors while studying online.

5. Students is anxious about problems or screen sharing failures for presentations.

6. Student has anxiety with learning system while studying online.

7. Student has anxiety that there will be a sound inserted while turning on the microphone, talking or doing activities with instructors and friends.

Overall

\begin{tabular}{|l|l|l|}
\hline 3.59 & 1.33 & High \\
\hline 4.36 & 0.98 & High \\
\hline 4.01 & 1.16 & High \\
\hline 3.93 & 0.99 & High \\
\hline 3.90 & 1.07 & High \\
\hline 3.77 & 1.17 & High \\
\hline 4.01 & 1.15 & High \\
\hline 3.94 & 1.12 & High \\
\hline
\end{tabular}

Additionally, they had leaning anxiety with online communication is at high level by the most items can be shown in following: student has anxiety that the Internet will fall off while studying online, student has anxiety that there will be a sound inserted while turning on the microphone, talking or doing activities with instructors and friends, and student has anxiety when submitting work, there is no response from the instructor in respectively.

The finding relevant to the previous studies, COVID-19 pandemic and learning environment, adaptation in teaching and learning activities, online and flexible learning in different school levels are reported (Aliyyah et al., 2020; Nuangchalerm et al., 2020; Azevedo et al., 2021; Duangpim et al., 2021; Nuangchalerm et al., 2021; Thongbunma et al., 2021; Wongjamnong et al., 2021). The learning anxiety is factor that influence to learning achievement due to students and instructors need to adapt with new normal classroom. Undergraduate science students had learning anxiety towards teaching and learning within pandemic era is at high level in all components. The time for instruction, it may be limited and condensed with online learning environment, devices and online accessories are learning aids, learning from home which seems to be freely (Dostál et al., 2017; Sosutha et al., 2021). 
Most of the teaching is available in both theoretical and online courses. As an its effect of the COVID-19 pandemic, students have been unable to adapt in time for the outbreak (Yates et al., 2021). Technology enhances students to deal with accessible knowledge and meet the windows of opportunity in learning strategies. The study required how to engage students facing with the modern world with necessary learning skills, learn to survive with cultural, social, and environmental awareness (Janpleng \& Ruangmontri, 2021). Even though students had level of learning anxiety in overall at high level, they can adapt themselves to find learning strategies in successful (Mookdamuang et al., 2019).

However, students have anxiety in online learning by mean of new normal learning and adaptation towards technology-enhanced instruction faster than educators thought. There has been a change in daily life, a change from teaching from regular classrooms to on-line classes. They can deal with anxiety based on the current state of affairs, they will be able to respond to the anxiety that they are currently facing. Time, instruction, and online communication are related to their virtual classroom. The limitation of this study needs to be more deep understandings about various factors affecting to decrease learning anxiety than those online learning. The instructional strategies and support system are may be more their stress within pandemic (Pimthong, 2018; Mahmood, 2021).

\section{Conclusion}

Students had leaning anxiety at the high level, they have to adapt with new learning environments and technology-enhanced learning. Instructors might want to give them much more time to take the examination, and do assignments. Video on demands and teaching strategies are sensitively employed in new normal classroom. The learning anxiety will be relieved, if time is manipulated with anytime and anywhere, but assignments and examination should aware to them. Also, instructional strategies may be prepared based on flexible learning through the time of pandemic.

\section{Acknowledgements}

This research project is financially supported by Mahasarakham University.

\section{References}

Aliyyah, R. R., Rachmadtullah, R., Samsudin, A., Syaodih, E., Nurtanto, M., \& Tambunan, A. R. S. (2020). The perceptions of primary school teachers of online learning during the COVID-19 pandemic period: A case study in Indonesia. Journal of Ethnic and Cultural Studies, 7(2), 90-109. https://doi.org/10.29333/ejecs/388

Azevedo, J. P., Hasan, A., Goldemberg, D., Geven, K., \& Iqbal, S. A. (2021). Simulating the potential impacts of COVID-19 school closures on schooling and learning outcomes: A set of global estimates. The World Bank Research Observer, 36(1), 1-40. https://doi.org/10.1596/ 1813-9450-9284

Bond, M. (2020). Schools and emergency remote education during the COVID-19 pandemic: A living rapid systematic review. Asian Journal of Distance Education, 15(2), 191-247. https://doi.org/10.5281/zenodo.4425683 
Dostál, J., Wang, X., Steingartner, W., \& Nuangchalerm, P. (2017). Digital intelligence-new concept in context of future school of education. Proceedings of ICERI2017 Conference November 16-18, 2017. https://doi.org/10.21125/iceri.2017.0997

Duangpim, K., Khamhueng, P., Kaewpikul, A., \& Nuangchalerm, P. (2021). Learning from home behavior: Looking beyond learning opportunity and non-opportunity. Gagasan Pendidikan Indonesia, 2(2), 74-80. https://doi.org/10.30870/gpi.v2i2.12910

Engzell, P., Frey, A., \& Verhagen, M. D. (2021). Learning loss due to school closures during the COVID-19 pandemic. Proceedings of the National Academy of Sciences, 118(17), 1-7. https://doi.org/10.1073/pnas.2022376118

George, M. L. (2020). Effective teaching and examination strategies for undergraduate learning during COVID-19 school restrictions. Journal of Educational Technology Systems, 49(1), 23-48. https://doi.org/10.1177/0047239520934017

Hamilton, L. S., \& Ercikan, K. (2022). COVID-19 and US schools: Using data to understand and mitigate inequities in instruction and learning. Primary and Secondary Education during COVID-19 (pp. 327-351). Springer, Cham. https://doi.org/10.1007/978-3-030-81500-4_13

Janplne, J., \& Ruangmontri, K. (2021). Elements of the teacher development system in learning management according to the concept of Education 4.0. Journal of Green Learning, 1(1), 22-27. https://doi.org/10.53889/jgl.v1i1.30

Kraft, M. A., Simon, N. S., \& Lyon, M. A. (2021). Sustaining a sense of success: The protective role of teacher working conditions during the COVID-19 pandemic. Journal of Research on Educational Effectiveness, 14(4), 727-769. https://doi.org/10.1080/19345747. 2021.1938314

Mahmood, S. (2021). Instructional strategies for online teaching in COVID-19 pandemic. Human Behavior and Emerging Technologies, 3(1), 199-203. https://doi.org/10.1002/ hbe 2.218

Marome, W., \& Shaw, R. (2021). COVID-19 response in Thailand and its implications on future preparedness. International Journal of Environmental Research and Public Health, 18(3), 1089. https://doi.org/10.3390/ijerph18031089

Mookdamuang, A., Saenubol, K., Charupheng, M., \& Charoensuk, O. (2019). A study of executive function factor of university students. Journal of Education, Mahasarakham University, 13(4), 25-36.

Nuangchalerm, P., Prachagool, V., \& Dostál, J. (2020). Digital learning of pre-service teachers during COVID-19 outbreak. Journal of Technology and Information Education, 12(2), 143-151. https://doi.org/10.33650/pjp.v8i1.1946

Nuangchalerm, P., Wongjamnong, C., \& Muangou, C. (2021). Opinions of students and teachers in primary school towards online learning during COVID-19 outbreak. Pedagogi: Jurnal Ilmu Pendidikan, 21(1), 30-35. https://doi.org/10.24036/pedagogi.v21i1.1006 
Nuankaew, P., Nasa-Ngium, P., Phanniphong, K., Chaopanich, O., Bussaman, S., \& Nuankaew, W. S. (2021). Learning management impacted with COVID-19 at higher education in Thailand: Learning strategies for lifelong learning. International Journal of Engineering Pedagogy, 11(4), 58-80. https://doi.org/10.3991/ijep.v11i4.20337

Pal, D., Vanijja, V., \& Patra, S. (2020). Online learning during COVID-19: Students' perception of multimedia quality. Proceedings of the 11th International Conference on Advances in Information Technology (pp. 1-6). https://doi.org/10.1145/3406601.3406632

Phattanawasin, P., Toyama, O., Rojanarata, T., Laopoonpat, P., Pochanakom, K., Limmatvapirat, C., ... Niratisai, S. (2021). Students' perspectives and achievements toward online teaching of medicinal chemistry courses at pharmacy school in Thailand during the COVID-19 pandemic. Journal of Chemical Education, 98(10), 3371-3378. https://doi.org/ 10.1021/acs.jchemed.1c00606

Pimthong, P. (2018). Integrating technology into project-based learning in a science curriculum development course. Journal of Education, Mahasarakham University, 12(4), 115-128.

Polydoros, G., \& Alasona, N. (2021). Teaching and learning during the COVID-19 pandemic. Journal of Research and Opinion, 8(6), 2954-2963. https://doi.org/10.15520/jro.v8i6.107

Sosutha, C., Wijakkanalan, S., \& Nuangchalerm, P. (2021). Exploring possibility of flexible learning management for teacher preparation program. Solid State Technology, 64(2), $2270-2276$.

Thanavisuth, C. (2021). Students' perceptions of online learning during the COVID-19 pandemic: A study of undergraduate students from an international university, Thailand. $A U$ Virtual International Conference Entrepreneurship and Sustainability in the Digital Era (Vol. 2, No. 1, pp. 382-387).

Thongbunma, J., Nuangchalerm, P., \& Supakam, S. (2021). Secondary teachers and students' perspectives towards online learning amid the COVID-19 outbreak. Gagasan Pendidikan Indonesia, 2(1), 1-9. https://doi.org/10.30870/gpi.v2i1.10524

Wongjamnong, C., Muangou, C., \& Nuangchalerm, P. (2021). Opinions of students and teachers in primary school towards online learning during COVID-19 outbreak. Pedagogi: Jurnal Ilmu Pendidikan, 21(1), 30-35. https://doi.org/10.24036/pedagogi.v21i1.1006

Yates, A., Starkey, L., Egerton, B., \& Flueggen, F. (2021). High school students' experience of online learning during COVID-19: The influence of technology and pedagogy. Technology, Pedagogy and Education, 30(1), 59-73. https://doi.org/10.1080/1475939X.2020.1854337 


\section{Copyright Disclaimer}

Copyright for this article is retained by the author(s), with first publication rights granted to the journal.

This is an open-access article distributed under the terms and conditions of the Creative Commons Attribution license (http://creativecommons.org/licenses/by/3.0/). 